J. Reprod. Fert. (1974) 38, 493-496

\title{
PROTEINS AND AMINO ACIDS IN BOVINE OVIDUCAL FLUID
}

\author{
D. F. STANKE, * J. D. SIKES, D. W. DeYOUNG $\dagger$ \\ AND M. E. TUMBLESON
}

Department of Dairy Husbandry, Department of Veterinary Physiology and Pharmacology, and Sinclair Research Farm, University of Missouri, Columbia, Missouri 65201, U.S.A.

(Received 3rd January 1974)

Oviducal fluid is important in the reproductive process because of its key function in relation to fertilization and early development of the embryo. Hafez \& Blandau (1969) reported an abundance of information concerning the fluid and its function in several species but only a limited amount of information is available on protein and amino acid concentration in bovine oviducal fluids. Olds \& VanDemark (1957) published data on bovine fluids obtained by stripping slaughterhouse reproductive tracts.

Fahning, Schultz \& Graham (1967) collected uterine fluid from adult dairy cows during various stages of the oestrous cycle and analysed it for free amino acid content. Loe, Roussel \& Patrick (1970) reported on the protein and amino acid content of fluids collected from dairy heifers using the technique described by Fahning et al. (1966). The work of Carlson, Black \& Howe (1970) was the first report of continuous collection and protein analysis of oviducal fluids from the cow. This project was designed to study protein and free amino acid concentrations in oviducal fluid during various phases of the oestrous cycle.

Oviducal fluids were collected continuously from two nulliparous 18-monthold Holstein dairy heifers. Animals were observed in oestrus before surgery and were considered to be reproductively normal by visual appraisal of the reproductive tract at the time of surgery. One end of a double-walled silicone cannula, described by Stanke, DeYoung, Sikes \& Mather (1973), was sutured into the ampullary end of the left oviduct, the other end was brought to the surface and 24-hr samples were collected in a sterile glass vial.

The oviducal fluid was stored at $-20^{\circ} \mathrm{C}$ until it was analysed. Samples were prepared for amino acid analysis by deproteinizing with a $10 \%$ sulphosalicylic acid solution. Analyses were performed by column chromatography (Beckman Model 116; Palo Alto, California). The protein fractions were separated electrophoretically, using the microzone technique on cellulose polyacetate strips stained with ponceau $S$, and were quantified using a densitometer (Model R; Gelman Instrument Co., Ann Arbor, Michigan).

* Present address: Department of Agriculture, Southwest Missouri State University, Springfield, Missouri, U.S.A.

$\dagger$ Present address: Department of Veterinary Clinical Service, Iowa State University, Ames, Iowa, U.S.A. 
All the values for total protein, free amino acids and protein fractions presented in this paper are from fluids collected from the same two animals. Samples from each animal were analysed independently, and values reported are means of daily samples when the volumes were sufficient for all the analyses, or of composite samples of 2 or 3 days during the later stages of the cycle.

The volumes of fluid $(\mathrm{ml} / 24 \mathrm{hr})$ collected during the four stages of the cycle in terms of mean values \pm S.E. were: oestrus, $5 \cdot 31 \pm 1 \cdot 57$; metoestrus, $3 \cdot 60 \pm$ 0.55 ; dioestrus, $1.49 \pm 0.11$; pro-oestrus, $1.36 \pm 0.34$. The volume collected followed a definite cyclic pattern and a significantly $(P<0.05)$ larger volume was collected during the period of oestrogen dominance.

There were no significant differences in protein values reported for different stages of the oestrous cycle (Table 1). The values for total protein are between the $12.2 \%$ protein found by Olds \& VanDemark (1957), using fluids from slaughterhouse tracts, and the $0.120 \mathrm{~g} / 100 \mathrm{ml}$ value reported by Carlson et al. (1970) who made continuous collections of oviducal fluids. Iritani, Gomes \&

Table 1. Total protein, albumin, $\alpha$-globulin, $\beta$-globulin and $\gamma$-globulin concentrations in bovine oviducal fluid

\begin{tabular}{l|c|c|c|c|c|c}
\hline $\begin{array}{c}\text { Stage of } \\
\text { cycle }\end{array}$ & $\begin{array}{c}\text { Total } \\
\text { protein }\end{array}$ & Albumin & $\alpha$-Globulin & $\beta$-Globulin & $\gamma$-Globulin & $\begin{array}{c}\text { Albumin } \\
\text { globulin } \\
\text { ratio }\end{array}$ \\
\hline Oestrus & $5 \cdot 20 \pm 0 \cdot 80$ & $2 \cdot 18 \pm 0 \cdot 27$ & $0 \cdot 67 \pm 0 \cdot 09$ & $0 \cdot 64 \pm 0 \cdot 12$ & $1 \cdot 71 \pm 0 \cdot 33$ & $0 \cdot 73 \pm 0 \cdot 05$ \\
Metoestrus & $4 \cdot 04 \pm 0 \cdot 32$ & $1 \cdot 84 \pm 0 \cdot 12$ & $0 \cdot 28 \pm 0 \cdot 04$ & $0 \cdot 50 \pm 0 \cdot 05$ & $1 \cdot 42 \pm 0 \cdot 16$ & $0 \cdot 82 \pm 0 \cdot 06$ \\
Dioestrus & $4 \cdot 76 \pm 0 \cdot 20$ & $2 \cdot 06 \pm 0 \cdot 08$ & $0 \cdot 56 \pm 0 \cdot 04$ & $0 \cdot 63 \pm 0 \cdot 05$ & $1 \cdot 51 \pm 0 \cdot 09$ & $0 \cdot 78 \pm 0 \cdot 03$ \\
Pro-oestrus & $5 \cdot 01 \pm 0 \cdot 60$ & $2 \cdot 17 \pm 0 \cdot 18$ & $0 \cdot 64 \pm 0 \cdot 10$ & $0 \cdot 64 \pm 0 \cdot 06$ & $1 \cdot 56 \pm 0 \cdot 27$ & $0 \cdot 78 \pm 0 \cdot 06$ \\
\hline
\end{tabular}

Values are given in $\mathrm{g} / 100 \mathrm{ml}$ and are expressed as means \pm S.E.

VanDemark (1969) reported protein concentrations of $3.0 \mathrm{~g} / 100 \mathrm{ml} 0$ to 4 days, and $2.4 \mathrm{~g} / 100 \mathrm{ml} 5$ to 16 days, after oestrus in the ewe. The values in Table 1 are also higher than those found by Moghissi (1970) in women and Perkins \& Goode (1966) in ewes. Total protein values reported here increased in concentration near oestrus, a trend indicated earlier by Iritani et al. (1969).

Concentrations of albumin, $\alpha$-globulin, $\beta$-globulin and $\gamma$-globulin found in bovine oviducal fluid are listed in Table 1 . Albumin is most abundant followed by $\gamma$-globulin and then $\alpha$-globulin and $\beta$-globulin at somewhat lower levels. Shapiro, Jentsch \& Yard (1971) reported the presence of these proteins in rabbit oviducal fluid with albumin being most abundant. Marcus \& Saravis (1965) noted the same proteins in monkey oviducal fluid but found it necessary to concentrate the fluid in order to demonstrate the presence of $\gamma$-globulin. Mastroianni, Urzua \& Stambaugh (1970), working with monkey oviducal fluid, found an additional protein band following ovulation that was not evident in the fluids described in this paper. Feigelson \& Kay (1972) reported a protein migrating as a pre-albumin in rabbit oviducal fluid that was not found in bovine oviducal fluid.

The free amino acid content of oviducal fluid was determined using composite samples for the various stages of the cycle. The results of the free amino acid analysis showed only slight variation from animal to animal (Table 2). 
A total of twenty free amino acids was found in bovine oviducal fluid. Threonine, asparagine and glutamine were present in only an occasional sample while the other seventeen were found consistently during all stages of the cycle (Table 2).

Iritani, Nishikawa, Gomes \& VanDemark (1971) reported nineteen free amino acids in both oviducal and uterine fluids of rabbits. Fahning et al. (1967) found a total of twenty-five free amino acids and amino compounds in uterine fluids collected from cattle.

Glycine, glutamic acid, alanine, lysine and arginine were found to be present in the greatest amounts in bovine oviducal fluid. Iritani et al. (1971) reported glycine, alanine, glutamic acid, valine, leucine, serine and lysine as being most abundant in bovine oviducal fluid. Loe et al. (1970) reported threonine as being abundant in bovine uterine fluid while it was found only in an occasional sample by this group of researchers. Glutamic acid, glycine, arginine, and lysine exhibited substantial changes in concentration during the cycle while those of the remaining amino acids showed little variation.

Table 2. Concentrations of free amino acids in bovine oviducal fluid collected during various stages of the oestrous cycle

\begin{tabular}{|c|c|c|c|c|}
\hline Amino acid & Oestrus & Metoestrus & Dioestrus & Pro-oestrus \\
\hline $\begin{array}{l}\text { Ornithine } \\
\text { Lysine } \\
\text { Histidine } \\
\text { Arginine } \\
\text { Aspartic acid } \\
\text { Serine } \\
\text { Glutamic acid } \\
\text { Glycine } \\
\text { Alanine } \\
\text { Valine } \\
\text { Methionine } \\
\text { Isoleucine } \\
\text { Leucine } \\
\text { Tyrosine } \\
\text { Phenylalanine } \\
\text { Cystine } \\
\alpha \text {-Aminoadipic }\end{array}$ & $\begin{array}{r}20 \cdot 3 \\
50.4 \\
15.8 \\
52.9 \\
6.9 \\
4.7 \\
52.2 \\
58.3 \\
45.6 \\
21.6 \\
5.6 \\
14.1 \\
19.7 \\
9.6 \\
11.0 \\
2.8 \\
7.2\end{array}$ & $\begin{array}{r}20 \cdot 0 \\
50 \cdot 4 \\
14 \cdot 7 \\
56 \cdot 6 \\
6 \cdot 7 \\
3 \cdot 9 \\
54 \cdot 8 \\
53 \cdot 8 \\
42 \cdot 7 \\
21 \cdot 7 \\
4 \cdot 9 \\
12 \cdot 9 \\
24 \cdot 9 \\
8 \cdot 4 \\
12 \cdot 1 \\
2 \cdot 1 \\
6 \cdot 7\end{array}$ & $\begin{array}{r}21 \cdot 3 \\
52 \cdot 4 \\
15 \cdot 4 \\
36 \cdot 7 \\
6 \cdot 8 \\
4 \cdot 7 \\
55 \cdot 8 \\
81 \cdot 7 \\
51 \cdot 9 \\
24 \cdot 8 \\
4.6 \\
13 \cdot 0 \\
27.5 \\
10.9 \\
12.9 \\
2.6 \\
6.2\end{array}$ & $\begin{array}{c}18 \cdot 7 \\
28 \cdot 5 \\
15 \cdot 1 \\
43 \cdot 2 \\
5 \cdot 8 \\
4 \cdot 9 \\
4 \cdot 6 \\
69 \cdot 7 \\
53 \cdot 5 \\
21 \cdot 8 \\
4 \cdot 2 \\
14 \cdot 3 \\
25 \cdot 3 \\
10 \cdot 1 \\
10 \cdot 2 \\
\text { Trace } \\
7 \cdot 5\end{array}$ \\
\hline
\end{tabular}

Values are given in $\mu \mathrm{g} / \mathrm{ml}$.

There were no observed relationships between the volumes of oviducal fluid secreted and the concentrations of proteins or amino acids found during any stage of the cycle, which is in agreement with Iritani et al. (1969). The increased volume of oviducal fluid accompanied by an elevation in total protein and amino acid concentrations indicated an oestrogen stimulation. Sugawara (1970) reported an increase in amino acid levels in the developing rat blastocyst possibly indicating a metabolic function of amino acids during this early stage of development. If free amino acids are essential to gamete development, a thorough knowledge of the amino acids present in oviducal fluid and their concentrations would be paramount to understanding gamete growth and development in vitro. 
Contribution from the Missouri Agriculture Experiment Station. Journal Series No. 6583. Approved by the Director. Supported in part by USPHS Grant RR-00285.

\section{REFERENCES}

Carlson, D., Black, D. L. \& Howe, G. R. (1970) Oviduct secretion in the cow. F. Reprod. Fert. 22, 549.

Fahning, M. L., Schultz, R. H. \& Graham, E. F. (1966) A technique for collection of uterine fluids from the live cow. Vet. Rec. 79, 230.

Fahing, M. L., Schultz, R. H. \& Graham, E. F. (1967) The free amino acid content of uterine fluids and blood serum in the cow. 7 . Reprod. Fert. 13, 229.

Feigelson, M. \& Kay, E. (1972) Protein patterns of rabbit oviducal fluid. Biol. Reprod. 6, 244.

Hafez, S. E. \& Blandau, R. J. (1969) The Mammalian Oviduct. University of Chicago Press.

Iritani, A., Gomes, W. R. \& VanDemark, N. L. (1969) Secretion rates and chemical composition of oviduct and uterine fluids in ewes. Biol. Reprod. 1, 72.

Iritani, A., Nishikawa, Y., Gomes, W. R. \& VanDemark, N. L. (1971) Secretion rates and chemical composition of oviduct and uterine fluids in rabbits. F. Anim. Sci. 33, 829.

Loe, W. C., Roussel, J. D. \& Patrick, T. E. (1970) Protein and amino acid content of uterine and oviduct fluid of dairy heifers. 7. Dairy Sci. 53, 662, Abstr.

Marcus, S. L. \& Saravis, G. A. (1965) Oviduct fluid in the Rhesus monkey: a study of its protein components and its origin. Fert. Steril. 16, 785.

Mastroianni, L., Jr, Urzua, M. \& Stambaugh, R. (1970) Protein patterns in monkey oviductal fluid before and after ovulation. Fert. Steril. 21, 817.

Moghissi, K. S. (1970) Human Fallopian tube fluid. I. Protein composition. Fert. Steril. 21, 821.

Olds, D. \& VanDemark, N. L. (1957) Composition of luminal fluids in bovine female genitalia. Fert. Steril. 8, 345.

Perkins, J. L. \& Goode, L. (1966) Effects of stage of the estrous cycle and exogenous hormones upon the volume and composition of oviduct fluid in ewes. F. Anim. Sci. 24, 465.

Shapiro, S. S., Jentsch, J. P. \& Yard, A. S. (1971) Protein composition of rabit oviducal fluid. $\mathcal{F}$. Reprod. Fert. 24, 403.

Stanke, D. F., DeYoung, D. W., Sikes, J. D. \& Mather, E. C. (1973) Collection of bovine oviduct secretions. 7. Reprod. Fert. 32, 535.

Sugawara, S. (1970) Incorporation of $\mathrm{C}^{14}$-L-leucine into rat eggs. Jap. J. Anim. Reprod. 15, Suppl. 12. 